Aleksander Gradowski*

https://doi.org/10.18778/8220-375-2.11

\title{
Rozpoznawalność i upamiętnienie Tadeusza Kościuszki w społeczeństwie amerykańskim w kontekście współczesnych relacji USA-Polska
}

\begin{abstract}
Recognition and commemoration of Tadeusz Kościuszko in American society in the context of contemporary US-Poland relations

When talking about people who influence the shaping of Polish-American relations, one of the first characters to come to mind is without a shadow of doubt Tadeusz Kościuszko. The purpose of the following paper is to discuss the most important factors that allowed the creation of the legend of Tadeusz Kościuszko in the United States, and to illustrate to what extent Tadeusz Kościuszko's person is commemorated and recognized among the American population. The purpose of this paper is also to answer the questions, what is his role in public discourse and Polish-American diplomacy, as well as what role does his character play in the functioning of the Polish community in the United States. The work was based on the historical research method. In the course of its creation, monographs, press articles, and internet sources in Polish and English were used. The subject of the research is determining Tadeusz Kościuszko's recognition, description of all issues related to commemorating him, as well as emphasizing the importance of his character for mutual relations between Poland and the United States, both in matters concerning diplomatic aspects and all social feelings manifested in both nations to each other.
\end{abstract}

Keywords: Tadeusz Kościuszko, Polish-American relations, commemoration, national hero, image of the state

Słowa kluczowe: Tadeusz Kościuszko, relacje polsko-amerykańskie, upamiętnienie, bohater narodowy, wizerunek państwa

\section{Wstęp}

Kiedy mówimy o osobach mających wpływ na kształtowanie się relacji polsko-amerykańskich, jedną z pierwszych postaci przychodzących na myśl jest bez cienia wątpliwości Tadeusz Kościuszko. Jako znamienitemu inżynierowi

\footnotetext{
"Absolwent studiów I stopnia, kierunek stosunki międzynarodowe, specjalność polityka międzynarodowa i dyplomacja na Wydziale Studiów Międzynarodowych i Politologicznych Uniwersytetu Łódzkiego, student studiów II stopnia, kierunek stosunki międzynarodowe, specjalność interamerykańska WSMiP UŁ; e-mail: aleksander.gradowski1@unilodz.eu.
} 
wojskowemu, brevet generałowi brygady w Armii Kontynentalnej, który (podobnie jak generał Kazimierz Pułaski) wsławił się walką w wojnie o niepodległość Stanów Zjednoczonych, udało mu się odcisnąć trwały ślad w historii tego państwa. Jego działalność na terenie Stanów Zjednoczonych, fakt, że pochodził z Polski, jak również to, jak go zapamiętano, rzutuje bezpośrednio na postrzeganie Polski oraz Polaków przez obywateli amerykańskich, a także wpływa na wzajemne relacje pomiędzy obydwoma krajami. Celem niniejszego artykułu jest wskazanie najważniejszych czynników, które zbudowały legendę Tadeusza Kościuszki w Stanach Zjednoczonych i określenie, w jakim stopniu postać ta jest rozpoznawalna i upamiętniana wśród społeczności amerykańskiej. Opracowanie ma też odpowiedzieć na pytanie, czy Tadeusz Kościuszko odgrywa istotną rolę w dyskursie publicznym, jak jego postać oddziałuje na życie społeczeństwa polonijnego oraz jaki jest jego wpływ na dyplomację polsko-amerykańską.

W pracy zastosowana została historyczna metoda badań. Została ona napisana $\mathrm{w}$ oparciu o monografie, artykuły prasowe oraz źródła internetowe w języku polskim i angielskim. Przedmiot badań stanowi określenie rozpoznawalności Tadeusza Kościuszki i wszelkich aspektów jej upamiętnienia, a także podkreślenie wagi tej postaci dla wzajemnych relacji między Polską i Stanami Zjednoczonymi, zarówno w kontekście dyplomacji, jak i występujących w obu narodach nastrojów społecznych względem siebie.

\section{Rys historyczny zasług Tadeusza Kościuszki dla Stanów Zjednoczonych}

Tadeusz Kościuszko przybył do Filadelfii w sierpniu 1776 roku i jako inżynier, których wówczas brakowało w armii amerykańskiej, postanowił, że zaoferuje swoją służbę George'owi Washingtonowi, ówczesnemu głównemu dowódcy Armii Kontynentalnej. Zanim jednak udało mu się spotkać z Washingtonem, jego losami zajął się Benjamin Franklin, który odpowiadał w tym czasie za koordynację czynności mających na celu zapewnienie bezpieczeństwa i wzmocnienie obronności Pensylwanii. „Będąc już w podeszłym wieku, Kościuszko w rozmowie ze swoim prywatnym sekretarzem wspominał swoje początki w nowym kraju”. Z jego relacji wynika, że podczas rozmowy z Franklinem został zapytany o listy polecające, na co odrzekł: „Nie mam żadnych. Człowiek z talentem powinien pokazać swą zdatność, a nie listy rekomendacjonalne, i ja z tego, co umiem, chcę zdać examen”. Po tych słowach zdumiony Franklin postanowił przyjrzeć się bliżej Kościuszce i poprosił go o zdanie relacji z sytuacji politycznej w Europie, przedstawienie swoich poglądów politycznych i informacji o swoim pochodzeniu. Stwierdziwszy, że odpowiedzi Kościuszki są satysfakcjonujące, powiedział: „Przekonywam się o twoich czystych i szlachetnych intencjach"1.

\footnotetext{
${ }^{1}$ A. Storozynski, Kościuszko. Książę chłopów, Warszawa 2018, s. 45.
} 
Za sprawą Franklina, który polecił sprawdzenie umiejętności i kompetencji Kościuszki, wyszło na jaw, że Polak jest nadzwyczaj uzdolnionym strategiem, w efekcie czego już 30 sierpnia 1776 roku został on przydzielony przez Kongres Kontynentalny do Departamentu Wojny Stanów Zjednoczonych jako specjalista do prac przy fortach. Dla Kościuszki było to niesamowite osiągnięcie, a zarazem awans, bo, mimo że posiadał ogromny talent, to jednak był całkowicie nieznany. Nie posiadał jeszcze doświadczenia bojowego, nie był również absolwentem szkoły wojskowej dla inżynierów, nie umiał nawet porozumiewać się w języku angielskim. Amerykanie, z uwagi na ogromne braki kadrowe, musieli jednak dać mu szansę wykazania się:

Inżynier odpowiedzialny do tej pory za stworzenie projektu fortyfikacji Filadelfii, będącej jednocześnie miejscem spotkań Kongresu Kontynentalnego, nie był w stanie dojść do porozumienia z przełożonymi. Równolegle wojska amerykańskie zostały pokonane w bitwie pod Long Island przez siły brytyjskie, którym udało się przejąć kontrolę nad Nowym Jorkiem, skutkiem czego było podjęcie przez Washingtona decyzji o odwrocie ${ }^{2}$.

Można powiedzieć, że w tamtej chwili Kościuszko był ostatnią deską ratunku dla osłabionych Amerykanów. Zajęcie przez Brytyjczyków pozbawionej obrony Filadelfii wpłynęłoby negatywnie na morale walczących o niepodległość obywateli amerykańskich, zatem nie było chwili do stracenia. Kościuszko, na polecenie Washingtona, rozpoczął pracę od skonstruowania fortu Billingsport. Z uwagi na niewystarczające zasoby oraz brak czasu zbudowane tam fortyfikacje nie były zbyt spektakularne, jednak dostatecznie solidne, by $\mathrm{w}$ razie potrzeby odeprzeć brytyjski atak. Następnie Polak dostał zadanie polegające na zaprojektowaniu fortyfikacji miasta na rzece Delaware. „Jego plan zakładał ukrycie stanowisk strzeleckich i utrudnienie możliwości przepływu statków przez rzekę poprzez wbicie w jej dno zaostrzonych pali. Kościuszko był także odpowiedzialny za wzniesienie dwóch innych fortów, mianowicie fortu Mercer i fortu Mifflin"3.

W uznaniu jego zasług, 18 października 1776 roku Kościuszko został awansowany na stopień pułkownika inżynierii w Armii Kontynentalnej4:

Sam przewodniczący Kongresu amerykańskiego John Hancock wystosował do Kościuszki list, w którym napisał: My, pokładając szczególną ufność i zaufanie w Pański patriotyzm, dzielność, zachowanie się

${ }^{2} \mathrm{R}$. Kowalczyk, Taki awans byt możliwy tylko w Ameryce. Jak Tadeusz Kościuszko trafit do Departamentu Wojny USA?, https://ciekawostkihistoryczne.pl/2019/06/13/taki-awans-byl-mozliwy-tylko-w-ameryce-jak-tadeusz-kosciuszko-trafil-do-departamentu-wojny-usa/ (dostęp: 27.03.2020).

${ }^{3}$ Ibidem.

${ }^{4}$ Ibidem. 
i wierność, niniejszym pismem mianujemy i ustanawiamy Pana inżynierem w randze pułkownika w armii Stanów Zjednoczonych, utworzonej dla obrony amerykańskiej wolności i dla odparcia wszelkiej nieprzyjacielskiej inwazji. [...] I my ściśle polecamy i żądamy od wszystkich oficerów i żołnierzy będących pod Pana rozkazem, aby byli posłuszni Pańskim rozkazom jako inżyniera ${ }^{5}$.

Na początku 1777 roku Kościuszko został wysłany pod granicę kanadyjską, gdzie umacniał obronę obozów wojskowych. Sławę zyskał dzięki przeprowadzeniu działań fortyfikacyjnych i budowie fortecy na Wzgórzach Bemisa znajdujących się nad rzeką Hudson. $Z$ jego rozkazu w błyskawicznym tempie zbudowano tam potężne reduty, szańce oraz klasyczne stanowiska ogniowe, co uczyniło to miejsce niemal niemożliwym do zdobycia przez Brytyjczyków ${ }^{6}$.

Jego działania, zdaniem licznych historyków, istotnie przyczyniły się do zwycięstwa Amerykanów w bitwie pod Saratogą ${ }^{7}$. Był to moment przełomowy w historii amerykańskiej wojny o niepodległość, ponieważ właśnie z powodu wyniku tej bitwy Francja podjęła decyzję o dołączeniu do Stanów Zjednoczonych w wojnie z Wielką Brytanią. Najwyższym wyrazem szacunku i uznania wobec Kościuszki było powierzenie mu przez prezydenta USA prac nad budową twierdzy West Point ${ }^{8}$. „Warto też zaznaczyć, że do zasług Kościuszki zalicza się także własnoręczne wykonanie ogrodów znajdujących się wokół West Point, do których podchodził z pasją, samodzielnie przynosząc ziemię w koszykach i wysypując ją na skalisty grunt" . Od tamtego czasu z ogrodów korzystają kadeci najistotniejszej amerykańskiej uczelni wojskowej ${ }^{10}$. Za udział w stworzeniu West Point Kościuszko do dziś jest uważany za symbolicznego „ojca amerykańskich fortyfikacji ${ }^{11}$ ". Został on również uhonorowany przyjęciem w poczet członków Towarzystwa Cyncynatów, zrzeszającego jedynie najbardziej zasłużonych dla sprawy amerykańskiej oficerów.

$\mathrm{Na}$ uwagę zasługuje też druga charakterystyczna strona działalności Kościuszki w Stanach Zjednoczonych, której podstawami są jego skromność, pra-

${ }^{5}$ Pisma Tadeusza Kościuszki. Wybrał, objaśnił i wstępem poprzedził H. Mościcki, Warszawa 1947, s. 258.

${ }^{6} \mathrm{P}$. Worwa, Na Wzgórzach Bemisa czyli jak Tadeusz Kościuszko uratowat amerykańska niepodległość, https://historykon.pl/nowe/na-wzgorzach-bemisa-czyli-jak-tadeusz-kosciuszko-uratowal-amerykanska-niepodleglosc/ (dostęp: 2.04.2020).

${ }^{7}$ Ibidem.

${ }^{8}$ M. Montowski, A. Storożyński, Bitwa pod Saratogq - sukces Tadeusza Kościuszki, https:// www.polskieradio.pl/39/156/Artykul/1234770,BitwapodSaratoga\%e2\%80\%93sukcesTadeuszaKosciuszki (dostęp: 18.04.2020).

${ }^{9}$ L. Pastusiak, Polacy w zaraniu Stanów Zjednoczonych, Warszawa 1977, s. 70.

${ }^{10} \mathrm{~W}$. Kalwat, W Ameryce rodzit się republikanizm Kościuszki oparty na wierze $w$ wolność $i$ walke wszystkich obywateli o niepodlegtość, https://kultura.gazetaprawna.pl/artykuly/1078096, kosciuszkobohaterusaipolski.html (dostęp: 27.03.2020).

${ }^{11}$ Ibidem. 
wość i postawa prospołeczna. Można zaryzykować stwierdzenie, że jego szlachetność jest o wiele bardziej istotna od jego umiejętności wznoszenia fortyfikacji. Tadeusz Kościuszko był niespotykanie pracowity, jednak w odróżnieniu od wielu równych mu rangą i wiedzą ludzi, nie zależało mu na pozycji i prestiżu. Praca, którą wykonywał dla dobra publicznego, była dla niego celem samym w sobie, toteż przez pewien czas pracował prawie za darmo ${ }^{12}$.

Wśród osób przebywających w West Point Kościuszko powszechnie uchodził za człowieka dobrotliwego. Będąc świadkiem wymierzania kary żołnierzowi, który dopuścił się jakiegoś przewinienia, niejednokrotnie potrafił stanąć $\mathrm{w}$ jego obronie u dowódcy. Kiedy na terenie twierdzy znajdowali się brytyjscy jeńcy wojenni, widząc ich niedolę, Kościuszko dzielił się z nimi własnym przydziałem racji żywnościowych ${ }^{13}$. Innym przykładem jego szlachetności może być postawa, jaką wykazał się w czasie bitwy pod Eutaw Springs. Powstrzymał on wówczas przeprowadzenie przez amerykańskich żołnierzy rzezi na liczącej kilkadziesiąt osób grupie brytyjskich jeńców ${ }^{14}$. Po głębszej analizie działalności Kościuszki można dojść do wniosku, że jego aktywność w kwestiach militarnych uzupełniała się doskonale z wartościami, które wyznawał, a w szczególności z wiarą w wolność dla wszystkich ludzi i wspólną walkę o niepodległość ${ }^{15}$.

Podczas swojego pobytu w Stanach Zjednoczonych Polak cieszył się bardzo dobrą opinią. W wielu kręgach był ceniony za swoje umiejętności i osiągnięcia na polu militarnym, dzięki którym nawiązał liczne przyjaźnie. Szwajcar Karol Falkenstein, który osobiście znał Kościuszkę w końcowym okresie jego życia, opisywał go tymi słowami:

W wielu bitwach i mniejszych potyczkach, łącząc z męstwem i wytrwałością niezłomną przezorność, rozwijając zdolność posiadanej wiadomości wojskowej, zasłużył na powszechne uwielbienie i imię jego z szacunkiem wszędzie wspominane było. Jenerałowie Gates i Greene zaszczycili go swoją przyjaźnią, która nawet i wtenczas nie ustała, gdy już był dawno do Europy powrócił, utrzymując z nim ciągłą i przyjemną korespondencją ${ }^{16}$.

\section{Upamiętnienie Kościuszki w Stanach Zjednoczonych}

Tadeusz Kościuszko, jako istotny twórca amerykańskiej historii, został upamiętniony na wiele różnych sposobów i w wielu miejscach w całych Stanach Zjednoczonych. Najważniejsze jest tu przede wszystkim muzeum Thaddeus Kosciuszko National Memorial, znajdujące się w Filadelfii, w budynku, który

\footnotetext{
${ }^{12}$ Ibidem.

${ }^{13}$ L. Pastusiak, op. cit., s. 70.

${ }^{14}$ Ibidem, s. 71.

${ }^{15}$ W. Kalwat, op. cit.

${ }^{16}$ K. Falkenstein, Tadeusz Kościuszko, czyli dokładny rys jego życia, 1827, s. 26.
} 
był domem Kościuszki pod koniec XVIII wieku. W chwili uzyskania przez dom statusu miejsca pamięci narodowej jego ówczesny właściciel oddał go pod zarząd Służby Parków Narodowych, dzięki czemu budynek odrestaurowano ${ }^{17}$. Powstały również liczne pomniki przedstawiające Tadeusza Kościuszkę ${ }^{18}$, a najbardziej znane z nich to: trzymetrowy posąg z brązu, odsłonięty w Bostonie w 1927 roku, monumentalny, mierzący cztery i pół metra pomnik konny, odsłonięty w Chicago w 1904 roku, pełen przepychu, wybudowany w 1978 roku, trzymetrowy monument znajdujący się w centrum Detroit, czy wreszcie pomnik znajdujący się w samym West Point, którego budowa, co ciekawe, odbyła się dwuetapowo. Najpierw dzięki funduszom zebranym przez kadetów uczelni na terenie kampusu w 1828 roku postawiona została kolumna z tablicą pamiątkową, natomiast w 1913 roku zwieńczono ją figurą Kościuszki wykonaną z brązu ${ }^{19}$.

Warto tutaj przywołać słowa przyszłego amerykańskiego prezydenta Williama Harrisona, wypowiedziane 6 stycznia 1818 roku w amerykańskim Kongresie. Zapowiedział on wówczas, że

Kościuszko, wybitny propagator wolności i praw człowieka (...) za zgodą całego świata będzie trwale uhonorowywany pomnikami, a jego sława trwać będzie tak długo, jak długo wolność panować będzie na Ziemi, dopóki świeca zapalana jest na ołtarzu, imię Kościuszki przywoływane będzie ${ }^{20}$.

Szczególnym przykładem uhonorowania Polaka może być również położona na Alasce Wyspa Kościuszki. Oprócz tego jest on patronem pensylwańskiego Klubu Sportowców Polskich Sokołów, gimnazjum w Hamtramck oraz współpatronem szkoły podstawowej w Winona. W Chicago zaś działa, założona w 1951 roku, Polska Szkoła im. Tadeusza Kościuszki, jedna z największych i najstarszych szkół języka polskiego w USA ${ }^{21}$. Co ciekawe, istnieją nawet dwie autostrady nazwane na jego cześć: Trakt Tadeusza Kościuszki, jako element Drogi nr 9 w Nowej Brytanii w Connecticut, oraz Autostrada Pamięci Generała Tadeusza Kościuszki, jako odcinek Trasy Państwowej nr 257. W Nowym Jorku natomiast znajduje się, zbudowany w 1939 roku, most Kościuszki, łączący dzielnice Greenpoint z Maspeth, które są bardzo licznie zamieszkiwane przez Amerykanów polskiego pochodzenia ${ }^{22}$. W 2017 roku most został wyburzony,

${ }^{17}$ F. Molski, Tadeusz Kościuszko upamiętniony na catym świecie, Kosciuszko Heritage Inc 2017, s. 37.

${ }^{18}$ W. Kowalski, A. Storożyński, Tadeusz Kościuszko - człowiek, który wyprzedzat swoje czasy, http:// muzhp.pl/pl/c/1355/tadeuszkosciuszkoczlowiekktorywyprzedzalswojeczasy (dostęp: 23.11.2019).

${ }^{19}$ F. Molski, op. cit., s. 32, 41, 43-44.

${ }^{20} \mathrm{Ibidem}$, s. 30.

${ }^{21}$ M. Pawlusiewicz, Historia Szkoty, https://www.szkolakosciuszki.com/o-nas (dostęp: 18.04.2020).

${ }^{22}$ Polska Agencja Prasowa, Most Kościuszki znów zachwyca. Amerykanie uczcili wielkiego Polaka, https://www.tvp.info/30144175/mostkosciuszkiznowzachwycaamerykanieuczciliwielkiegopolaka (dostęp: 18.04.2020). 
ale na jego miejsce postawiono nowy, zaś jego budowa została wyceniona na 755 milionów dolarów ${ }^{23}$.

Nieocenioną rolę $\mathrm{w}$ szerzeniu pozytywnego wizerunku generała pełni powołana w 1925 roku Fundacja Kościuszkowska. „Zajmuje się ona promowaniem wymian edukacyjnych i kulturowych pomiędzy Stanami Zjednoczonymi i Polską, a także zwiększaniem zrozumienia polskiej historii i kultury w społeczeństwie amerykańskim. Fundacja ta jest organizacją non-profit, a jej zasięg obejmuje całe Stany Zjednoczone za pośrednictwem jej siedziby głównej, położonej w Nowym Jorku, oraz regionalnych oddziałów znajdujących się w Chicago, Denver, Houston, Filadelfii, Pittsburgu, Springfield, Buffalo i Ohio" ${ }^{24}$. Fundacja jest finansowana przez osoby prywatne, inne fundacje i korporacje, które również zauważają konieczność i potrzebę realizacji misji polegającej na rozwijaniu stosunków polsko-amerykańskich.

Zadania Fundacji realizowane są zwłaszcza poprzez: organizację kampanii społecznych, których celem jest poprawa świadomości historycznej i społecznej; promowanie postaw patriotycznych; realizowanie badań dotyczących historii, a także problematyki relacji polsko-amerykańskich; organizację spotkań, konferencji, sympozjów, wykładów i wystaw oraz innych form przekazywania wiedzy historycznej. Jednak przede wszystkim to udzielanie wsparcia finansowego w postaci przyznawania stypendiów, jak również grantów badawczych pracownikom naukowym, wykładowcom, a także studentom chcącym studiować lub prowadzić projekty naukowe w placówkach uniwersyteckich, akademiach sztuki czy instytutach medycznych Stanach Zjednoczonych ${ }^{25}$.

Interesującą inicjatywą było również utworzenie w 2004 roku Amerykańskiego Stowarzyszenia Przyjaciół Kościuszki w West Point, którego głównym celem jest rozpowszechnianie wiedzy o generale i jego zasługach dla USA w społeczeństwie amerykańskim. Stowarzyszenie co roku, na terenie Akademii Wojskowej Stanów Zjednoczonych w West Point, organizuje tzw. Konferencję Kościuszkowską. Ma ona charakter akademicki i skupia naukowców, wykładowców uniwersyteckich, historyków, przedstawicieli wojska polskiego, jak również litewskiego, członków Ministerstw Obrony Narodowej Polski i Litwy, reprezentantów wydziału West Point oraz specjalistów do spraw stosunków międzynarodowych z Waszyngtonu ${ }^{26}$. Podczas konferencji starają się oni

\footnotetext{
${ }^{23}$ A. Gradowski, Rola historycznych postaci wojskowych w budowaniu pozytywnego wizerunku kraju na arenie międzynarodowej [praca licencjacka, maszynopis, WSMiP UŁ], Łódź 2019, s. 45.

${ }^{24}$ U.S. Mission Poland, Ambasada USA i Fundacja Kościuszkowska ogłaszają nowe stypendium dla uczczenia 100. rocznicy relacji polsko-amerykańskich, https://pl.usembassy.gov/pl/ambasada-usa-i-fundacja-kosciuszkowska-oglaszaja-nowe-stypendium-dla-uczczenia-100-rocznicy-relacji-polsko-amerykanskich/ (dostęp: 23.11.2019).

${ }^{25}$ The Kosciuszko Foundation, About us, https://www.thekf.org/kf/about/about_us/ (dostęp: 23.11.2019).

${ }^{26}$ A. Gradowski, op. cit., s. 47.
} 
naświetlać współczesne kwestie bezpieczeństwa, przed którymi stoi Unia Europejska, NATO, a także Stany Zjednoczone ${ }^{27}$.

Na szczególną uwagę zasługują oceny, jakie pod adresem Kościuszki kierowały światowe autorytety. Doskonałym przykładem mogą tu być opinie dwóch byłych prezydentów Stanów Zjednoczonych. Słowa Thomasa Jeffersona, który nazwał Polaka „najczystszym synem wolności, jakiego poznał, i to wolności dla wszystkich, a nie tylko dla nielicznych i bogatych"28, czy też myśl Thomasa Woodrowa Wilsona, dotycząca zwycięstwa w bitwie nad Saratogą, jako najważniejszego osiągnięcia Kościuszki, brzmiąca: „Sławny patriota polski Tadeusz Kościuszko był tym, który pokazał gen. Gatesowi, jak się okopać pod Bemis Heights", którą Wilson zawarł w dziele History of the American People ${ }^{29}$.

Nazwisko Kościuszki jest również wymieniane podczas oficjalnych spotkań i uroczystości. Jego postać wielokrotnie służyła do podkreślenia braterskich relacji łączących Polskę i Stany Zjednoczone. O generale ciepło wypowiadał się prezydent USA Bill Clinton, który podczas dorocznych obchodów miesiąca dziedzictwa polsko-amerykańskiego w 1996 roku zwrócił się do społeczności polonijnej słowami:

W tym roku obchodzimy 250. rocznicę urodzin wielkiego polskiego bohatera Tadeusza Kościuszki, który pomógł zapewnić niepodległość naszej nowo powstałej republice podczas wojny o niepodległość. (...) Przyłączam się do wszystkich Amerykanów w podziękowaniach dla naszych rodaków polskiego pochodzenia za ich nieoceniony wkład w siłę i jakość życia naszego narodu ${ }^{30}$.

Podobnie było w maju 2003 roku, podczas spotkania prezydenta USA George'a W. Busha oraz prezydenta RP Aleksandra Kwaśniewskiego, który przywitał amerykańskiego przywódcę słowami:

Walczyliśmy o wolność - dla siebie i - solidarnie - dla innych. Przypomina o tym postać Tadeusza Kościuszki - wielkiego bohatera polskiej i amerykańskiej historii. (...) Dowodem wierności tym ideałom jest także obecne partnerstwo naszych krajów w stawianiu czoła trudnym problemom współczesnego świata ${ }^{31}$.

\footnotetext{
${ }^{27} \mathrm{http} / / /$ www.kosciuszkoatwestpoint.org/whats_new.html (dostęp: 24.11.2019).

${ }^{28} \mathrm{~A}$. Włusek, 4 lutego 1746 roku urodził się Tadeusz Kościuszko, https://historykon.pl/nowe/4lutego1746urodzilsietadeuszkosciuszko/ (dostęp: 24.11.2019).

${ }^{29}$ L. Pastusiak, op. cit., s. 64.

${ }^{30}$ Public Papers of the Presidents of the United States: William f. Clinton, 1997, s. 1793.

${ }^{31}$ Oficjalna strona prezydenta Rzeczypospolitej Polskiej, Spotkanie Prezydenta RP z Prezydentem USA na Wawelu, https://www.prezydent.pl/aleksandrakwasniewskiego/aktualnosci/rok2003/ art,154,320,spotkanieprezydentarpzprezydentemusanawawelu.html (dostęp: 29.03.2020).
} 
W podobnym tonie wypowiadał się prezydent Bronisław Komorowski podczas spotkania z amerykańskim prezydentem Barackiem Obamą w 2014 roku. Powiedział wtedy: „Wystarczy przypomnieć Tadeusza Kościuszkę, Pan prezydent był w West Point, tam jest piękny pomnik Kościuszki (...) to przypomnienie swoistego partnerstwa broni sięgającego XVIII wieku"32. Natomiast w czasie wizyty polskiej pary prezydenckiej w Stanach Zjednoczonych w 2018 roku amerykański prezydent Donald Trump podkreślił, „że nic tak, jak postać Tadeusza Kościuszki i jego pomniki, stojące zarówno w polskich, jak i amerykańskich miastach, przypomina o niezwykłej » łączności między USA i Polską «" ${ }^{33}$.

Godne odnotowania są też słowa sekretarza stanu Stanów Zjednoczonych Mike'a Pompeo, którego przemówienie w formie materiału wideo zaprezentowano podczas obchodów 274. rocznicy urodzin Kościuszki 4 lutego 2020 roku w Mińsku. Pompeo nazwał Kościuszkę „bojownikiem o wolność, podkreślił jego zasługi dla amerykańskiej wojny o niepodległość, a także jego wkład w powstanie akademii wojskowej West Point. Swoje wystąpienie zakończył słowami: „Wszystkie nasze narody mogą z dumą odnotować jego wkład w naszą wolność" ${ }^{34}$. Nie bez znaczenia jest również gest ambasador Stanów Zjednoczonych w Polsce, Georgette Mosbacher, która w tym samym dniu zamieściła na Twitterze wpis o treści: „Dziś 274. rocznica urodzin Tadeusza Kościuszki, którego Thomas Jefferson, jeden z autorów Deklaracji Niepodległości USA, nazwał »najczystszym synem wolności«. Kościuszko jest zarówno polskim, jak i amerykańskim bohaterem narodowym!'”35 Warto przy tym zaznaczyć, że w 2018 roku uchwalono rezolucję ustanawiająca 15 października Dniem Kościuszki w stanie Wirginia i w mieście Nowy Jork ${ }^{36}$.

\section{Obecność Kościuszki w życiu społeczeństwa amerykańskiego}

Postać Tadeusza Kościuszki jest zazwyczaj nieodłącznym elementem uświetniającym spotkania i uroczystości organizowane przez Polonię amerykańską. Ideą tego typu spotkań jest nie tylko rozwijanie i pielęgnowanie relacji,

\footnotetext{
${ }^{32}$ Zespół wPolityce.pl, Prezydent USA w Polsce. Komorowski do Obamy: „F16 jak Fighter i Freedom!” Obama: „festeśmy sojusznikami razem i na zawsze”, https://wpolityce.pl/polityka/ 198919-prezydent-usa-w-polsce-komorowski-do-obamy-f-16-jak-fighter-i-freedom-obama-jestesmy-sojusznikami-razem-i-na-zawsze (dostęp: 29.03.2020).

${ }^{33}$ Wmeritum.pl, Andrzej Duda w USA: Donald Trump wspomina Tadeusza Kościuszkę, https:// wmeritum.pl/andrzejdudawusadonaldtrump/248249 (dostęp: 24.11.2019).

${ }^{34}$ Wszystkie nasze narody moga z duma odnotować jego wkład w nasza wolność, https://tvn24. pl/swiat/tadeusz-kosciuszko-urodzil-sie-274-lata-temu-3795060 (dostęp: 29.03.2020).

${ }^{35}$ O. Łozińska, G. Mosbacher: Kościuszko jest zarówno polskim, jak i amerykańskim bohaterem narodowym, https://dzieje.pl/aktualnosci/g-mosbacher-kosciuszko-jest-zarowno-polskim-jak-i-amerykanskim-bohaterem-narodowym (dostęp: 29.03.2020).

${ }^{36}$ Poland in English, NYC to Mark Poland's Independence Day, http://www.tvp.pl/polandinenglishinfo/news/politicseconomy/nyctomarkpolandsindependenceday/39788609 (dostęp: 24.11.2019).
} 
jakie łączą Polaków i Amerykanów, ale przede wszystkim poszerzanie wśród amerykańskiej społeczności znajomości historii związanej z Polakami, którzy wywarli wpływ na ukształtowanie się Stanów Zjednoczonych, jakie znamy dzisiaj. Dodatkowo pozwalają one na krzewienie świadomości narodowej wśród członków Polonii. Jednym z przejawów takiej aktywności może być tzw. Kongres 60 milionów, którego już dziewiąta edycja miała miejsce na początku października 2019 roku w Nowym Jorku. Kongres miał charakter edukacyjny, a jego program przewidywał wykłady i wystąpienia znamienitych przedstawicieli kultury, zarówno polskiej, jak i amerykańskiej. Wśród punktów spotkania znajdowały się: prelekcja na temat dziedzictwa Tadeusza Kościuszki w USA, zorganizowana przez weteranów i przedstawicieli organizacji wojskowych, zwiedzanie obiektów West Point, ze szczególnym uwzględnieniem dziedzictwa Kościuszki, oraz zdjęcia pamiątkowe przy jego pomniku na terenie kampusu uczelni ${ }^{37}$.

Jeśli mówimy o rozpoznawalności Tadeusza Kościuszki w społeczności polonijnej zamieszkującej Stany Zjednoczone, to badania świadomości historycznej przeprowadzone w ubiegłym roku napawają optymizmem. „Wskazują one bowiem, że jest on postacią dość powszechnie rozpoznawaną. Niemal każdy uczestnik badania o nim słyszał, zdecydowana większość badanych zaś kojarzy podstawowe fakty związane z jego życiem i działalnością na terenie Stanów Zjednoczonych"38. Zdecydowanie gorzej kwestia rozpoznawalności Kościuszki wygląda wśród zwykłych obywateli amerykańskich. O ile pewna część osób starszych kojarzy jego nazwisko i potrafi przynajmniej powierzchownie opisać kim był, o tyle w przypadku osób młodych odsetek ludzi dysponujących jakimkolwiek zasobem wiedzy na jego temat, staje się zatrważająco niski. Wynika to po części z rosnącego braku zainteresowania młodzieży amerykańskiej historią, ale także z braku powszechnego i łatwego dostępu do rzetelnych informacji dotyczących życia Kościuszki. Program nauczania szkół średnich uwzględnia wprawdzie przekazanie uczniom kilku suchych faktów dotyczących jego życiorysu, lecz najczęściej są to wzmianki lakoniczne i ulatujące z pamięci w natłoku innych informacji ${ }^{39}$. Osoba potencjalnie zainteresowana postacią Kościuszki musiałaby zatem wykazać się własną inicjatywą i poszukać wiadomości nieco głębiej aniżeli tylko w popularnych leksykonach.

Legenda Tadeusza Kościuszki jest dla Amerykanów o polskich korzeniach niezwykle ważna, ponieważ pozwala im kształtować w swojej społeczności

\footnotetext{
${ }^{37}$ Polska Agencja Prasowa, Kongres 60 milionów w Nowym forku. Celem promocja Polski i integracja Polonii, https://www.tvp.info/44709847/kongres60milionowwnowymjorkucelempromocjapolskiiintegracjapolonii (dostęp: 25.11.2019).

${ }^{38}$ A. Kruszyńska, Prof. A. Szwarc: Kościuszko byt postaciq znanq i podziwiana w całej Europie i na świecie, https://dzieje.pl/aktualnosci/prof-szwarc-kosciuszko-byl-postacia-znana-i-podziwiana-w-calej-europie-i-na-swiecie (dostęp: 26.11.2019).

${ }^{39}$ W. Kowalski, A. Storożyński, op. cit.
} 
swoiste poczucie dumy narodowej. „Duma ta wiąże się jednak nie tyle z polską kulturą i historią, co z historią Polaków żyjących w USA, tym, co udało im się osiągnąć, zarówno indywidualnie, jak i jako zbiorowości. Chodzi w tym przypadku zwłaszcza o tworzenie szkół, parafii, różnorakich instytucji kulturowych, gospodarczych i społecznych oraz rolę, jaką odgrywały osoby polskiego pochodzenia podczas konfliktów prowadzonych przez Stany Zjednoczone, a także współuczestniczenie w tworzeniu amerykańskiej kultury i przemysłu”40. Tadeusz Kościuszko, będąc odzwierciedleniem tych wszystkich cech, staje się symbolem nierozerwalnie związanym z historią Polaków zamieszkujących Stany Zjednoczone, a zarazem stanowi swego rodzaju spoiwo jednoczące Amerykanów polskiego pochodzenia i podtrzymujące polską tożsamość.

Na wzmiankę zasługuje w tym miejscu bez cienia wątpliwości fragment tekstu będącego częścią publikacji wydanej w 1932 roku przez Federalną Komisję Dwusetlecia Urodzin Waszyngtona, zatytułowanej Life and Time of George Washington. Głosi ona:

Historycy wskazują wielką rolę, jaką odegrał Kościuszko w bitwie pod Saratogą i w przygotowaniach do niej; a czyniąc to, wykazują, jaką nieocenioną wartość stanowił on dla sił amerykańskich. Gdyby w tym czasie odniósł był zwycięstwo Burgoyne, to w następstwie mogło ono z wielką łatwością spowodować zupełne pobicie kolonistów, a tym samym historia świata byłaby przybrała zupełnie inny obrót ${ }^{41}$.

Słowa te są bezprecedensowym dowodem na to, że zasługi Kościuszki dla społeczeństwa amerykańskiego są dostrzegane na szczeblu rządowym. Niestety, w historiografii tego kraju próżno jednak szukać dłuższych opisów dotyczących wkładu Kościuszki w walkę Stanów Zjednoczonych o niepodległość. Podręczniki najczęściej uwzględniają wprawdzie jego postać, ale są to zwykle pojedyncze i mocno ogólnikowe, wymienione w punktach informacje. Zauważyć należy jednocześnie, że Kościuszko spotyka się z istotnym zainteresowaniem ze strony amerykańskiego Kongresu i choć są to zazwyczaj jedynie okolicznościowe wspomnienia, towarzyszące różnym uroczystościom, to jednak z polskiego punktu widzenia jest to fakt godny podkreślenia ${ }^{42}$.

Warto też wspomnieć, że rok 2017 był w Stanach Zjednoczonych Rokiem Kościuszki. W celu podkreślenia dokonań Tadeusza Kościuszki dla wywalczenia przez Stany Zjednoczone niepodległości Ambasada Polski w Waszyngtonie zorganizowała wiele okolicznościowych atrakcji, między innymi projekcję

${ }^{40}$ T.C. Radzilowski, Polscy Amerykanie dzisiaj: badanie polonijnych liderów, http://biuletynmigracyjny.uw.edu.pl/dodatek36czerwiec2012/polscyamerykaniedzisiajbadaniepolonijnychliderow (dostęp: 26.11.2019).

${ }^{41}$ K. Wachtl, Polonia w Ameryce: dzieje i dorobek, Filadelfia 1944, s. 44.

${ }^{42}$ L. Pastusiak, op. cit., s. 96. 
filmu biograficznego o Kościuszce oraz konferencję historyczną, która odbyła się w Bibliotece Kongresu. Film zatytułowany Kościuszko, czyli wolność został nakręcony z intencją zaznajomienia młodych Amerykanów z historią życia generała. W założeniu miał on docierać głównie do użytkowników mediów społecznościowych, jednak jego popularność przerosła oczekiwania twórców.

Podczas tych obchodów odbył się również tzw. Bieg Wolności Kościuszki. Jego trasa została wytyczona wzdłuż otwartego w połowie XIX wieku kanału Chesapeake-Ohio, łączącego Waszyngton i miasto Cumberland, i zakończyła się uroczystym złożeniem wieńców pod pomnikiem generała przez ambasadora RP w Waszyngtonie, ambasadora Republiki Litewskiej oraz prezesa Kongresu Polonii. Pierwszy, inauguracyjny „Bieg Wolności Kościuszki” odbył się w 2016 roku i od samego początku cieszył się ogromną popularnością. Duże zainteresowanie, nie tylko wśród środowisk polonijnych, wzbudziła akcja Find Your Kosciuszko! (Znajdź Swego Kościuszkę!). Jej uczestnicy mieli za zadanie odszukać w najbliższym sąsiedztwie miasteczka, drogi, powiaty, mosty, parki, pomniki oraz inne miejsca noszące nazwę na cześć Tadeusza Kościuszki. W obchodach Roku Kościuszki uczestniczyli również przedstawiciele Fundacji Kościuszkowskiej i reprezentanci klubu zwanego „Eskadrą Kościuszki”, czyli kadeci z akademii wojskowej West Point. Uroczystości uświetnił występ znanego kwintetu trąbkowego piechoty Stanów Zjednoczonych.

Ambasador Rzeczypospolitej Polskiej w Stanach Zjednoczonych w przemówieniu skierowanym do społeczności amerykańskiej zwrócił uwagę, że „plany militarne Kościuszki miały istotne znaczenie dla przebiegu bitwy pod Saratogą 17 października 1777 roku. Przesądziła ona o uzyskaniu przez Stany Zjednoczone niepodległości”. Oprócz tego podczas uroczystości Frank Spula, prezes Kongresu Polonii Amerykańskiej, a jednocześnie szef towarzystwa ubezpieczeniowego o nazwie Związek Narodowy Polski, organizacji, z inicjatywy której ponad sto lat temu zbudowano pomnik Tadeusza Kościuszki na skwerze zwanym przez Amerykanów „parkiem La Fayette’a”, powiedział, że dla Amerykanów pochodzących z Polski Kościuszko nie jest jedynie narodowym bohaterem, ale także przykładem na to, że każda nacja może z powodzeniem włączyć się w główny nurt życia Stanów Zjednoczonych ${ }^{43}$.

\section{Podsumowanie}

Analiza powyższych rozważań skłania do wniosku, że Kościuszko słusznie jest nazywany „bohaterem dwóch narodów”, a na podstawie przeprowadzonego wywodu można stwierdzić, że udowodnione zostały następujące hipotezy:

\footnotetext{
${ }^{43}$ Redakcja niezalezna.pl, Minąt „Rok Kościuszki” w USA, https://niezalezna.pl/206007-minal-quotrok-kosciuszkiquot-w-usa (dostęp: 26.11.2019).
} 
1) Zasługi Tadeusza Kościuszki dla Stanów Zjednoczonych były ogromne, dlatego też do dziś oddawana jest mu w tym kraju należna cześć, a pamięć o nim jest stale kultywowana;

2) Jego polskie korzenie ułatwiają integrację Polonii z amerykańskim społeczeństwem, ponieważ wywołują w nim pozytywne skojarzenia;

3) Na gruncie dyplomacji postać Kościuszki również nadaje wzajemnym relacjom przyjazny ton, co w przypadku tak istotnego sojusznika jak USA jest niezwykle ważne.

Mimo że od jego śmierci upłynęło ponad dwieście lat, można by rzec, że Tadeusz Kościuszko nadal działa na rzecz i w interesie Polski, zapewniając jej w pewnym sensie poczucie wdzięczności ze strony jednego z najważniejszych uczestników stosunków międzynarodowych, jakim są bez wątpienia Stany Zjednoczone. Wartości, jakimi kierował się w życiu oraz sposób, w jaki traktował innych ludzi, pozwoliły mu zaskarbić sobie sympatię społeczeństw wielu krajów, w tym zwłaszcza Stanów Zjednoczonych, co niewątpliwie przełożyło się na sposób postrzegania Polski w świecie, a także jej pozycję na arenie międzynarodowej. Postać Tadeusza Kościuszki, ze względu na jego osiągnięcia, jak również działalność na rzecz ogółu, posiada istotny potencjał w kwestii rozbudowywania i wzmacniania relacji polsko-amerykańskich, zarówno na poziomie rządów, jak i społeczeństw, a co się z tym wiąże, świadectwo jego życia powinno być stale kultywowane i rozwijane. Zabiegi z tym związane moga w przyszłości okazać się owocne dla sojuszu obu państw, opartego na zasadach braterstwa i spajanego pamięcią o wspólnym bohaterze narodowym.

\section{Bibliografia}

Falkenstein F., Tadeusz Kościuszko, czyli dokładny rys jego życia, 1827.

Gradowski A., Rola historycznych postaci wojskowych w budowaniu pozytywnego wizerunku kraju na arenie międzynarodowej [praca licencjacka, maszynopis, WSMiP UŁ], Łódź 2019.

Kalwat W., W Ameryce rodzit się republikanizm Kościuszki oparty na wierze w wolność $i$ walkę wszystkich obywateli o niepodlegtość, https://kultura.gazetaprawna.pl/artykuly/1078096,kosciuszko-bohater-usa-i-polski.html (dostęp: 27.03.2020).

The Kosciuszko Foundation, About us, https://www.thekf.org/kf/about/about_us/ (dostęp: 23.11.2019).

Kowalczyk R., Taki awans byt możliwy tylko w Ameryce. Jak Tadeusz Kościuszko trafit do Departamentu Wojny USA?, https://ciekawostkihistoryczne.pl/2019/06/13/taki-awans-byl-mozliwy-tylko-w-ameryce-jak-tadeusz-kosciuszko-trafil-do-departamentu-wojny-usa/ (dostęp: 27.03.2020). 
Kowalski W., Storożyński A., Tadeusz Kościuszko - człowiek, który wyprzedzał swoje czasy, http://muzhp.pl/pl/c/1355/tadeusz-kosciuszko-czlowiek-ktory-wyprzedzal-swoje-czasy (dostęp: 23.11.2019).

Kruszyńska A., Prof. A. Szwarc: Kościuszko byt postaciq znana i podziwianq w catej Europie i na świecie, https://dzieje.pl/aktualnosci/prof-szwarc-kosciuszko-byl-postacia-znana-i-podziwiana-w-calej-europie-i-na-swiecie (dostęp: 26.11.2019).

Łozińska O., G. Mosbacher: Kościuszko jest zarówno polskim, jak i amerykańskim bohaterem narodowym, https://dzieje.pl/aktualnosci/g-mosbacher-kosciuszko-jest-zarowno-polskim-jak-i-amerykanskim-bohaterem-narodowym (dostęp: 29.03.2020).

Molski F., Tadeusz Kościuszko - upamiętniony na catym świecie, Kosciuszko Heritage Inc, 2017.

Montowski M., Storożyński A., Bitwa pod Saratoga - sukces Tadeusza Kościuszki, https: //www.polskieradio.pl/39/156/Artykul/1234770,Bitwa-pod-Saratoga-\%e2\%80\%93-sukces-Tadeusza-Kosciuszki (dostęp: 18.04.2020).

Oficjalna strona prezydenta Rzeczypospolitej Polskiej, Spotkanie Prezydenta RP z Prezydentem USA na Wawelu, https://www.prezydent.pl/aleksandra-kwasniewskiego/ aktualnosci/rok-2003/art,154,320,spotkanie-prezydenta-rp-z-prezydentem-usa-na-wawelu.html (dostęp: 29.03.2020).

Pastusiak L., Polacy w zaraniu Stanów Zjednoczonych, Warszawa 1977.

Pawlusiewicz M., Historia Szkoty, https://www.szkolakosciuszki.com/o-nas (dostęp: 18.04.2020).

Pisma Tadeusza Kościuszki. Wybrał, objaśnił i wstępem poprzedził H. Mościcki, Warszawa 1947.

Poland in English, NYC to Mark Poland's Independence Day, http://www.tvp.pl/polandinenglishinfo/news/politics-economy/nyc-to-mark-polands-independenceday/39788609 (dostęp: 24.11.2019).

Polska Agencja Prasowa, Kongres 60 milionów w Nowym forku. Celem promocja Polski $i$ integracja Polonii, https://www.tvp.info/44709847/kongres-60-milionow-w-nowym-jorku-celem-promocja-polski-i-integracja-polonii (dostęp: 25.11.2019).

Polska Agencja Prasowa, Most Kościuszki znów zachwyca. Amerykanie uczcili wielkiego Polaka, https://www.tvp.info/30144175/most-kosciuszki-znow-zachwyca-amerykanie-uczcili-wielkiego-polaka (dostęp: 18.04.2020).

Public Papers of the Presidents of the United States: William f. Clinton, 1997.

Radzilowski T.C., Polscy Amerykanie dzisiaj: badanie polonijnych liderów, http://biuletynmigracyjny.uw.edu.pl/dodatek-36-czerwiec-2012/polscy-amerykanie-dzisiaj-badanie-polonijnych-liderow (dostęp: 26.11.2019).

Redakcja Niezalezna.pl, Miną „Rok Kościuszki” w USA, https://niezalezna.pl/206007-minal-quotrok-kosciuszkiquot-w-usa (dostęp: 26.11.2019).

Storozynski A., Kościuszko. Ksią̇ę chłopów, Warszawa 2018.

U.S. Mission Poland, Ambasada USA i Fundacja Kościuszkowska ogłaszaja nowe stypendium dla uczczenia 100. rocznicy relacji polsko-amerykańskich, https://pl.usembassy. gov/pl/ambasada-usa-i-fundacja-kosciuszkowska-oglaszaja-nowe-stypendium-dla-uczczenia-100-rocznicy-relacji-polsko-amerykanskich/ (dostęp: 23.11.2019).

Wachtl K., Polonia w Ameryce: dzieje i dorobek, Filadelfia 1944. 
Włusek A., 4 lutego 1746 roku urodził się Tadeusz Kościuszko, https://historykon.pl/nowe/4-lutego-1746-urodzil-sie-tadeusz-kosciuszko/ (dostęp: 24.11.2019).

Wmeritum.pl, Andrzej Duda w USA: Donald Trump wspomina Tadeusza Kościuszkę, https://wmeritum.pl/andrzej-duda-w-usa-donald-trump/248249 (dostęp: 24.11.2019).

Worwa P., Na Wzgórzach Bemisa czyli jak Tadeusz Kościuszko uratowat amerykańskq niepodległość, https://historykon.pl/nowe/na-wzgorzach-bemisa-czyli-jak-tadeusz-kosciuszko-uratowal-amerykanska-niepodleglosc/ (dostęp: 2.04.2020).

Wszystkie nasze narody moga z duma odnotować jego wkład w nasza wolność, https:// tvn24.pl/swiat/tadeusz-kosciuszko-urodzil-sie-274-lata-temu-3795060 (dostęp: 29.03.2020).

Zespół w Polityce.pl, Prezydent USA w Polsce. Komorowski do Obamy: „F-16 jak Fighter i Freedom!” Obama: „,Jesteśmy sojusznikami razem i na zawsze”, https://wpolityce.pl/ polityka/198919-prezydent-usa-w-polsce-komorowski-do-obamy-f-16-jak-fighter-i-freedom-obama-jestesmy-sojusznikami-razem-i-na-zawsze (dostęp: 20.03.2020). 